\title{
Al Ethics Training in Higher Education: Competency Framework
}

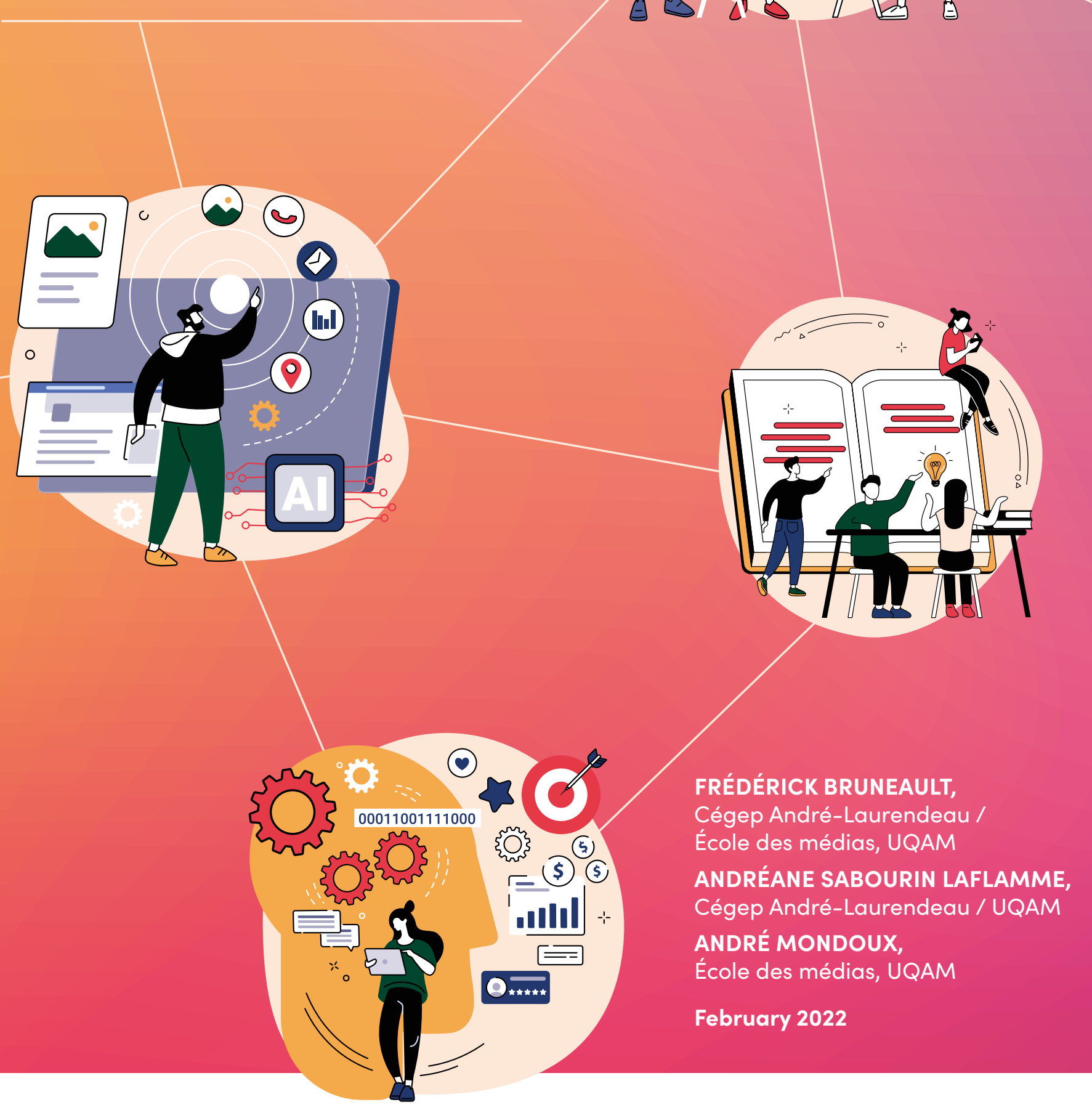




\section{Acknowledgements}

This research project was funded

by the Pôle montréalais d'enseignement

supérieur en intelligence artificielle (PIA).

Research Assistants

Geneviève Dugré,

UQAM

Catherine Mazerolle,

Cégep André-Laurendeau

Gabrielle Fillion,

Cégep André-Laurendeau

Interviewees

Neila Abtroun,

École de santé publique, Université de Montréal

Sylvain Auclair,

Cégep de Sainte-Foy / Université Laval

Philippe Beaudoin,

Waverly

Alexandre Blondin-Massé,

Département d'informatique, UQAM

Antoine Boudreau-Leblanc,

École de santé publique, Université de Montréal

Céline Castets-Renard,

Faculté de droit, Université d'Ottawa

Hugo Cyr,

Département des sciences juridiques, UQAM

Marc-Kevin Daoust,

École de technologie supérieure

Andrew Feenberg,

School of Communication, Simon Fraser University

Andrew Freeman,

Département de réadaptation /

Institut d'éthique appliquée, Université Laval

Sébastien Gambs,

Département d'informatique, UQAM

Mariana B. Ganapini,

Philosophy Department, Union College

Karine Gentelet,

Département des sciences sociales, UQO

Martin Gibert,

Centre de recherche en éthique de l'Université de Montréal / IVADO
Trystan Goetze,

Philosophy Department, Harvard University

Pierre-Léonard Harvey,

Département de communication sociale

et publique, UQAM

Steven Kelts,

Politics Department \& University Center

for Human Values, Princeton University

Lyse Langlois,

Faculté des sciences sociales, Université Laval /

Directrice, OBVIA

Jocelyn Maclure,

Department of Philosophy, McGill University

Allison Marchildon,

Département de philosophie et d'éthique

appliquée, Université de Sherbrooke

Dominic Martin,

École des sciences de la gestion, UQAM

Ajung Moon,

Department of Electrical \& Computer

Engineering, McGill University

Marie-Hélène Parizeau,

Faculté de philosophie, Université Laval

David Rocheleau-Houle,

Commission de l'éthique en science

et en technologie

Luke Stark,

Faculty of Information \& Media Studies,

Western University

Bryn Williams-Jones,

École de santé publique, Université de Montréal

Partners

Florence Sedaminou Muratet,

Éductive

Alexandre Enkerli,

Éductive

Marise Lachapelle,

Bureau de la recherche et de l'innovation, Cégep André-Laurendeau 


\section{Table of contents}

Introduction

Aims and Objectives

Methodology_ 6

Ethical competency___ 8

The components

of the ethical competency

The competency in $\mathrm{Al}$ ethics

Fields of competency

in $\mathrm{Al}$ ethics

Overview of the competency framework 16

Al ethics competency statement

The 3 components

of the ethical competency

The 3 components of the Al ethics competency

The 4 fields of competency

in Al ethics 19

Dimensions and elements of competency in Al ethics 20

Graphical representation of the Al ethics competency framework

Bibliography 


\section{Introduction}

The development of artificial intelligence (Al), which is dependent on the development of digital and information and communication technologies (ICT), is disrupting all spheres of the information society in which we live. Students, both as citizens and in their professional lives, will inevitably be called upon to interact with Al systems (AIS), which while promising major advances in many areas, raise many ethical issues. Al is more and more present in various employment environments, whether we think of the health, education, law, transportation, media or public administration sectors, and everything indicates that its use will increase in the coming years. In this context, it is imperative to train students on the societal impacts of Al in all areas of its application. Such training must conceptually equip students to develop autonomous reflection on the ethical issues that the impacts of the integration of ICT and AI raise, in accordance with the objectives of the Digital Competency Framework - Cadre de référence de la compétence numérique (Gouvernement du Québec, 2019). There are many skills related to Al ethics to be developed in higher education, both in technical and professional areas specific to Al and in media, social, political, medical, and legal studies.

Over the past decade, the literature on the ethical and social issues related to AIS has grown at a steady, if not accelerating, pace. We are witnessing a generalized awareness, which goes far beyond the academic community, of the many problems that can arise during the design, deployment and use of AIS in our societies. The interviews we conducted as part of this research project allowed us to observe that higher education institutions are increasingly concerned with ensuring that the students they train in their various programs and study profiles are aware of the transformations brought about by the integration of $\mathrm{Al}$ in their future professional environments and that they are equipped to deal with the issues that this integration may raise. The training offer in Al ethics, while still relatively limited, is growing rapidly in Québec, in Canada and in the main international centres. Whether it is in the form of courses entirely dedicated to $\mathrm{Al}$ ethics that are integrated into the curriculum, modules dedicated to these questions integrated into the various disciplinary training programs, complementary or extracurricular training, summer schools, microprograms or even one-off initiatives by professors, training in Al ethics is increasingly present in the various academic courses.

Although Al ethics is now recognised as a full-fledged branch of applied ethics - along with bioethics, animal ethics, or environmental ethics - and its body of work is in the process of consolidation, there is still no consensus on the essential components that an adequate and comprehensive training in Al ethics should include. Our research found that higher education in Al ethics is unfolding in each field of study relatively independently, e.g., in health, computer science, education, philosophy, law, management, media studies, etc. Moreover, the pedagogical approaches taken in higher education in $\mathrm{Al}$ ethics vary widely across settings, so this complicates the development of a unified understanding of the core competencies that should be acquired by an individual pursuing training in $\mathrm{Al}$ ethics. This competency framework aims to fill these gaps, with the goal of defining the competency expected of students upon completion of training in $\mathrm{Al}$ ethics in higher education, the components and elements of that competency, and the different fields specific to Al ethics in which the competency should be deployed. 


\section{Aims and Objectives}

The production of the Al ethics competency framework is in itself an effort to mobilize key actors in $\mathrm{Al}$ in Québec, given the many university and college networks that it brings together, thus creating an interdisciplinary community of interest around the ethical issues associated with the growing use of AIS in our societies. Through this mobilization, the objective is to allow a better understanding of these issues in order to foster commitment to the integration of an Al ethics competency in higher education. The document also aims to help establish the roles and responsibilities of each level of education in addressing the ethical challenges posed by Al, as well as to nourish the reflection of the various actors in the field of higher education regarding the vocation of training responsible citizens in relation with the social deployment of Al. One of the aims is that the competency framework can serve as a model for developing different types of training in Al ethics in higher education, training that will adequately provide conceptual tools to students in order to deal with the many issues that the integration of AIS raises in the various professional practice environments and in the various spheres of citizen activity.
Being transferable to all fields of application of Al, since they all raise unavoidable ethical issues, the competency framework can serve as a reference document regarding the competencies required for quality training in $\mathrm{Al}$ ethics, both in the college and university contexts, as well as in the teaching of philosophy and applied ethics, in the social sciences, and in the technical and professional fields affected by Al deployment. The model of the competency framework can be mobilized by the various actors in the higher education community - program directors, professors, pedagogical advisors, ICT specialists, etc. - in the context of the renewal or development of the training in Al ethics. The objective is that this document can be used as a tool by higher education institutions who seek to develop training programs in the field of Al ethics, whether they take the form of courses entirely dedicated to this issue, modules integrated into an existing training program, or complementary or extra-curricular academic activities. The competency framework has also been written in such a way that it can be adapted to different teaching contexts, depending on the discipline, program, level, or particularities of different higher education institutions. Although the framework was designed primarily for the academic setting, we believe it could also be used in different contexts, such as Al ethics training in business or government.

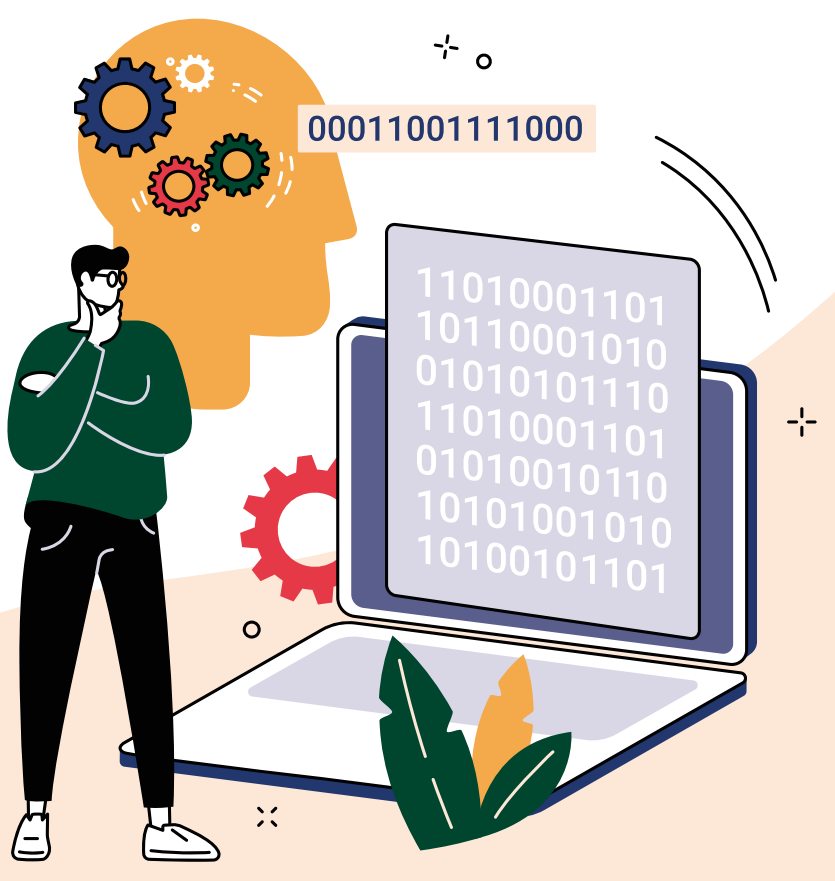




\section{Methodology}

The development of the framework was carried out in three parts: a literature review, a survey of the training offer in Al ethics in higher education in Québec, and interviews with researchers, professors and professionals who have developed an expertise in teaching Al ethics in their professional practice.

\section{Literature Review}

First, the researchers, supported by research assistants, conducted a literature review that was consolidated around five distinct themes:

1. Al ethics teaching

2. Digital technology and computer ethics teaching

3. Al ethics

4. The ethical competency

5. The competency-based approach in education

Although Al is a technology that has been around since the 1950s, its rapid development and integration into our various spheres of activity - due in part to the increased computing power of computers - is relatively recent. It is therefore not surprising that the scientific literature that specifically addresses the teaching of Al ethics remains rather limited to this day. For this reason, we have determined that it would be appropriate to broaden our research focus to include the teaching of Tech ethics, Digital ethics and Computer ethics, which have a broader heritage than Al ethics and from which we have drawn to define the Al ethics competency.

In order to situate our reflection on the teaching of Al ethics within this emerging field of applied ethics, we have sought to identify the different approaches, trends and schools of thought that characterize this field of study. While reflections on the ethical issues associated with Al have appeared since the birth of this science in the 1950s (Wiener, 1950), the literature in Al ethics has experienced an unprecedented growth in the last decade. Indeed, our research has allowed us to observe a real proliferation of publications in Al ethics, whether they come from academia, professional backgrounds, governmental and non-governmental organizations, industry or the general media. Given the multiplication of publications in Al ethics and the fact that this corpus is constantly evolving, we have focused our attention more specifically on publications with a more general purpose and which, starting from a literature review dedicated to a particular field of Al ethics, aim for example to identify and analyze the main issues associated with this technology, (Mittelstadt et al., 2016; Tsamados et al., 2021), to identify the different approaches and schools of thought in Al ethics (Maclure and Saint-Pierre, 2018; Bruneault and SabourinLaflamme, 2021) or to list the recurring ethical principles in the numerous charters, declarations and guidelines that have been published in recent years (Jobin et al, 2019; Floridi and Cowls, 2019; Fjeld et al., 2020).

Of course, a successful reflection on the competency in Al ethics cannot be conducted without a reflection on what characterizes the ethical competency in a more general way. The literature review dedicated to the ethical competency that we conducted allowed us to target the different approaches related to the definition and development of this competency as well as to identify the most promising avenues that could constitute a starting point from which to define the Al ethics competency (Marchildon, 2017; Lacroix et al., 2017; Boudreau, 2019). Finally, we also looked at different perspectives on the notion of competency itself, so as to situate the competency framework within this discussion. 


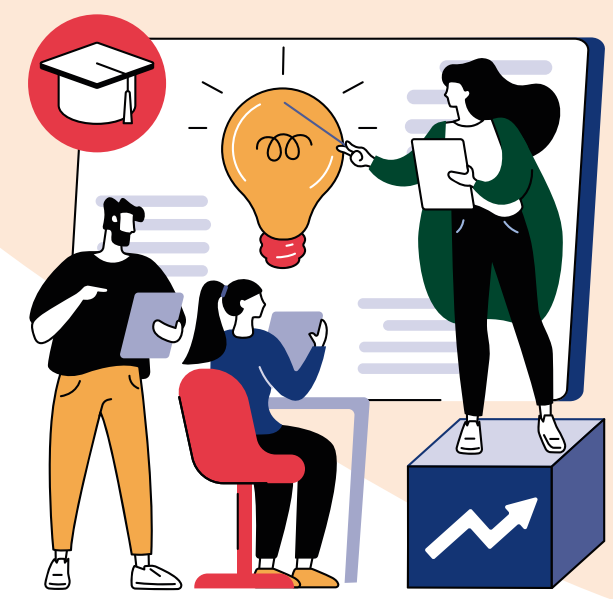

\section{Review of the Al ethics training offer in higher education in Québec}

Based on the information available in the sections of the websites dedicated to the different programs offered by colleges and universities in Québec, and assisted by two research assistants, we have listed the different training courses in Al ethics offered by Quebec's higher education institutions. More specifically, we conducted a survey of courses dedicated to $\mathrm{Al}$ ethics in the various programs offered by these institutions as well as courses that, without being entirely dedicated to this issue, include content specifically dedicated to Al ethics, with the objective of drawing a general portrait of $A I$ ethics training in Québec's higher education system. The analysis of the research results allowed us to conclude that, while the offer is quite limited, a large proportion of the courses listed are relatively recent initiatives. We also collected and analyzed several course syllabi, which allowed us to measure the diversity of approaches in the teaching of Al ethics.

\section{Interviews with experts in Al ethics}

We gathered the opinions of several individuals with expertise in Al ethics or related fields (in Al development, in technology ethics, or in the societal and legal impacts of Al). The 26 individual interviews we conducted were designed to identify the teaching practices and pedagogical approaches taken by those involved in teaching Al ethics. We asked those who had experience teaching Al ethics to describe their courses in Al ethics or related fields, discussed the teaching methods and innovations they saw as most promising, gathered their views on the essential components and objectives of a satisfactory training in Al ethics, and asked them to identify the competencies that students taking such training should develop. The list of people we met is available in the section dedicated to acknowledgements. We were then able to compile the information collected and intersect the different opinions, which gave us a general picture of the different approaches and interpretations of these issues. We were also able to organize, in collaboration with Éductive, a living lab on the competency framework, which allowed us to present the model developed in the framework and to gather comments and proposals from several people specialized in education, ethics teaching or involved in the development of Al. A preliminary version of the competency framework was also presented at a workshop attended by the research members of the Ethics, governance and democracy axis of the International Observatory on the Societal Impacts of Al and Digital Technology (OBVIA). This participatory process allowed for the collection of opinions, comments and suggestions from professionals and experts who have an academic background and who have developed an expertise in Al ethics. 


\section{Ethical competency}

The Al ethics competency of course presupposes the ethical competency in general. Defining the ethical competency presents specific difficulties. Being characterized more by global attitudes and behaviors in problematic situations rather than by specialized operations, the definition of the ethical competency must consequently reflect this aspect. Being ethically competent cannot be reduced to knowing and applying ethical theories, or only to behaving according to pre-established rules, nor to internalizing professional obligations. Based on recent work on the ethical competency (Boudreau, 2019), we have concluded that such approaches - cognitive, behaviourist and functional respectively - are incomplete and do not allow us to consider the complexity of this competency, nor its deployment in context. Therefore, we adopt, in this competency framework, a dynamic approach to the ethical competency (Boudreau, 2019) which implies not only an interaction between the components of the cognitive, behaviourist and functional approaches, but even more a synthesis of these elements in the understanding of problematic situations. Furthermore, Boudreau (2019) distinguishes between conceptions of the ethical competency that emphasize compliance with pre-established rules (or theoretical approaches, or codes of ethics) from those that instead emphasize the necessarily reflexive dimension of ethics, which requires reflection on the validity of those ethical rules or norms themselves.

We therefore adopt a conception of the ethical competency that is both dynamic and reflexive, which is in line, as Boudreau (2019) points out, with a pragmatist approach to ethics. As Lacroix, Marchildon and Bégin (2017) have pointed out, such an approach, which is rooted in the philosophical movement of American pragmatism - especially the founding writings of Charles Sanders Peirce, William James and John Dewey - has considerable advantages for thinking about the ethical competency according to a dynamic and reflective conception. We can present the interest of such an approach around three main characteristics of the pragmatist approach identified by Keulartz et al (2002), namely 1- antifoundationalism, 2- anti-dualism and 3- anti-skepticism.

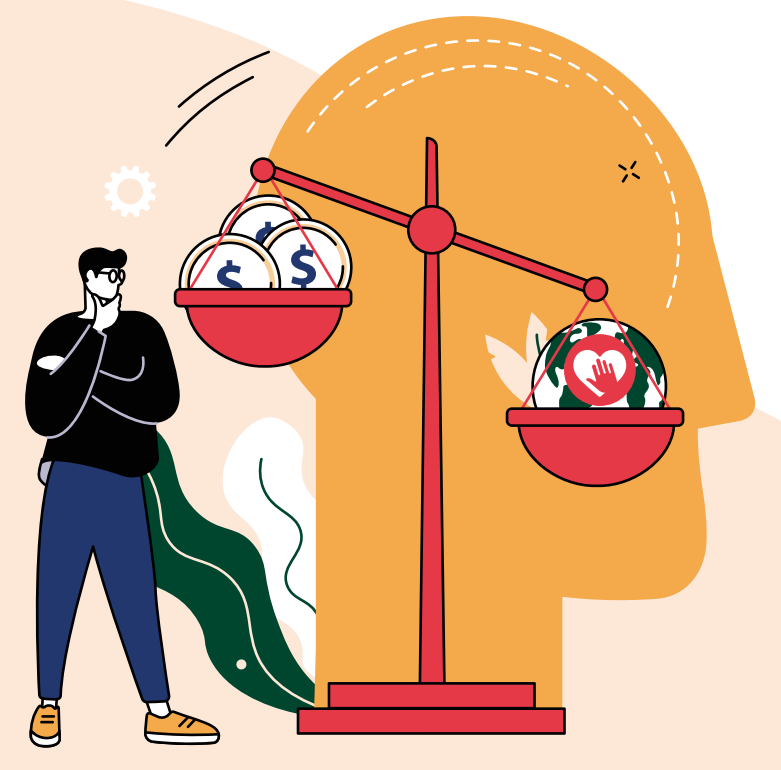


1- Anti-foundationalism refers to the fallibilism of pragmatist approaches. The idea of fallibilism stipulates that all our knowledge is subject to questioning and that every part of it is therefore subject to revision. In this sense, there is no single fundamental principle that could be the basis of all our knowledge, a principle that would itself be unquestionable. From this perspective, then, one would have to reject an approach that postulates a single principle (as defined by classical ethical approaches) as the foundation of the other moral obligations from which we can make an ethical assessment. While the three major classical approaches in ethics - namely deontologism, consequentialism and virtue ethics - stipulate (at least implicitly) that the principle from which they build their ethical approach is first and should serve as the foundation for all other moral obligations to which we are subject, a pragmatist ethics approach will instead seek to develop what we might call, following van den Hoven (2010), a mid-level theory, which will allow to address the specific problems that Al may create, without reducing the solution to these problems to the full application of a specific principle from traditional ethical theories. Moreover, such an integral application of classical ethical theories would suppose that it would be possible to settle once and for all the theoretical debates on these different classical ethical frameworks that have marked the history of philosophy and that continue to mobilize the attention of many philosophers, which seems unlikely.
2- The anti-dualism of pragmatists refers to their refusal to essentialize or to reify the main concepts and oppositions from which we understand ourselves and analyze the world. It is well known that many philosophical debates concern the dichotomy between mind and matter, between facts and values, between knowledge and appearances or between the individual and society. Pragmatist philosophers seek to challenge such dichotomies. Indeed, while they may be useful for thinking about problematic situations, pragmatists question the idea of making them substantial realities and thus reifying these oppositions, which has the effect of dragging philosophical discussion into endless debates, especially about the delimitation of these supposedly essentially distinct spheres. While these distinctions are certainly useful in allowing us to analyze situations and reflect on the problems that may be generated with the development of $\mathrm{Al}$, it is necessary to refrain from thinking of these different elements as if they were substantial realities independent of each other. One must keep in mind that these elements establish relations between themselves, relations that must ultimately be interpreted as a continuum showing intrinsic tensions, but that can also be thought of in a coevolutionary relationship. We believe that this is particularly important for thinking about the specific problems generated by Al. 
3- The anti-skepticism of pragmatist approaches finally refers to the role of doubt in philosophical analysis, the central idea being that questioning our knowledge must be motivated by specific problematic situations, whereas doubting absolutely everything is in turn impractical (and inefficient). Although pragmatist ethics rejects foundationalism (putting instead forward fallibilism, as we have seen above), pragmatist thinkers do not however support a relativistic interpretation of our moral obligations. Indeed, pragmatist approaches, also rejecting skepticism, hold that all our knowledge and ideas are open to question, but that it is impossible to question them all at once. Pragmatist ethics thus rejects the skeptical position of questioning all forms of knowledge (and all principles) and instead focuses on a critical examination of certain elements of knowledge (or principles) based on the practices in which these elements are mobilized. This last characteristic thus highlights the idea of inquiry that is central to pragmatist epistemology. Ethical assessment, like other forms of knowledge production, requires an inquiry which, while relying on an inescapable theoretical background, aims at reconsidering the principles from which such an assessment can be carried out. This work of inquiry, in the ethical assessment of $\mathrm{Al}$, must therefore be seen as a deliberative examination aiming at answering specific problems and examining the issues related to the definition of ethical principles and conceptual tools that are able to contribute to the ethical assessment of these technological innovations. This process of inquiry may involve both the need to redefine or reconceptualize certain principles from classical ethical frameworks as well as to prioritize them so that they allow us to better understand the issues themselves and find specific solutions to these problems (Coeckelbergh, 2021). It is therefore a matter of starting from contextual and specific practices in order to generate an inquiry that will allow us to elaborate conceptual work that can both help us better understand the issues themselves and find specific solutions to these problems.
Echoing the work of Lacroix et al. (2017) on these issues, we can therefore argue that a pragmatist approach to the ethical competency is particularly interesting for our purpose. For this reason, we adopt their definition of the ethical competency, namely that "to be ethically competent is to be able to act in ethical situations autonomously and responsibly through the voluntary mobilization of appropriate internal and external resources" (Lacroix et al., 2017: 112 , our translation). It is interesting to note here four features of this definition:

1- It is about "being competent" in ethics, not "having a competence" in ethics, which emphasizes the behavioral dimension of this competency.

2- Action presupposes a constant and continuous interaction between the individual and her environment (rather than a separation between these two poles).

3- The idea of voluntary action allows us to underline the conative dimension of the ethical competency, the will being a fundamental characteristic of the ethical aspect of the chosen action, thus echoing the idea of autonomy and freedom.

4- The very notion of "ethical situation" refers to the fact that the ethical approach and the ensuing action always operate from a particular context that offers internal and external resources that can be mobilized for voluntary action, since ethical problems cannot be examined from a totally external position. 


\section{The components of the ethical competency}

This definition of the ethical competency allows us to think about its dynamic dimension by identifying three essential components (Lacroix et al., 2017):

\section{1- Being in an ethical situation (Ethical sensitivity)}

The first of these components implies that "being in a situation presupposes at the very least an ability of the actor to 'experience' a rupture, an imbalance, a disturbance in the course of her actions" (Lacroix et al., 2017: 101, our translation). Referring to the notion of "experience" in Dewey (2004), this sensitivity to the ethical dimension of problematic situations must allow to appreciate these situations in their complexity of their ramifications. Now, it appears that "being in an ethical situation is not something as spontaneous, natural and easy as it appears at first sight", so that "being able to experience such destabilizations thus becomes a major issue of the ethical competency" (Lacroix et al., 2017: 104, our translation). It is by developing this first component of the ethical competency that the competent person can engage in the search for avenues leading to the resolution of these situations.

\section{2- Knowing how to act in an ethical situation (Reflective skills)}

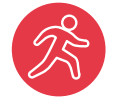

This second component of the ethical competency, knowing how to act in an ethical situation, implies acquiring and developing the resources necessary for action, since "competent action in an ethical situation expresses a practical intelligence of ethical situations. It is a practical intelligence in that a) it proceeds from a mobilization of resources (both internal and external) in order to; b) adequately understand the ethical situation that challenges the actor; and c) produce an adapted response - if necessary an imaginative and inventive response - to the environment triggering the work of this practical intelligence" (Lacroix et al., 2017: 106, our translation). To understand and analyze the elements characterizing the problematic situation and to consider possible solutions to the destabilization it generated, the person who acts must mobilize internal resources, both conative and cognitive, as well as external resources that are social. "It is by becoming aware of her own practices and ways of assuming her roles - personal, professional and social - in response to the expectations and norms addressed to her that the actor gives herself the possibility of opening up to thoughtful transformations of her ways of responding to ethical situations" (Lacroix et al., 2017: 108, our translation).

\section{3- Interacting in an ethical situation (Dialogical skills)}

This brings us to the third component of the ethical competency, namely interacting in an ethical situation. The actions of the person who acts are always part of a horizon of meaning that is based on social interaction, since "even transactions with the physical environment are strongly dependent on the actor's interactions with her social environment [...] there are always social meanings that are mobilized during such transactions [...] what the actor does is thus based on a background of socially marked and shared meanings, conventional uses and habits of social interaction: the actor's relationship to her social meanings allows and guides the processing of the resources at her disposal" (Lacroix et al., 2017: 109, our translation). This is particularly important with regard to the ethical competency, which directly challenges the relationship with others. The ethical competency requires: 1- attention to others' experience of the ethical situation; 2- the dialogical capacity that allows one to stabilize the social environment from which the situation is apprehended; and 3- the willingness to be accountable - and therefore responsible - for one's own actions in relation to others. It follows that "ethical situations always involve a range of socially constructed notions and concepts through which the claims to orient the conduct of people are expressed. It will be according to her understanding and uses of these notions and concepts that the actor will appreciate and construct what is problematic in the ethical situation; it is also through these that she will be able to relate to others and initiate with them a course of action aimed at achieving a desired result" (Lacroix et al., 2017: 109-110, our translation). 
The three components of the ethical competency, in accordance with the dynamic conception, interact with each other in a synchronous way, the components supporting and reinforcing each other. Therefore, they are three interdependent components of one and the same ethical competency, since "interacting with others is something that manifests itself as soon as we enter an ethical situation by a necessary attention to others. To be in an ethical situation is in fact already to be involved in interactions with others which will participate in destabilizations calling for a new course of action. To act in an ethical situation is in turn inseparable from these interactions. Both the competent problematization of the ethical situation and the determination of the solutions and results to be achieved imply, from the outset, a dialogical capacity as well as a willingness to answer for one's choices and actions" (Lacroix et al., 2017: 112 , our translation). The ethical competency therefore implies being able to combine these different components.

\section{The competency in Al ethics}

We thus believe that the competency in Al ethics can be stated as follows:

To be competent in Al ethics is to be able to act in ethical situations involving Al systems, and to do so autonomously and responsibly through the voluntary mobilization of appropriate internal and external resources.

It goes without saying that the three components of the ethical competency that have just been highlighted are part of the competency in Al ethics. However, since we are dealing with the ethical competency applied to a specific context, we believe that in addition to these three components adapted to Al ethics, we must also identify four fields of competency in Al ethics in order to underline the different spheres of application of the ethical competency related to the design, development and deployment of this technology.

\section{Fields of competency in Al ethics}

Since the components of the ethical competency can only be deployed in the assessment of specific situations, it is necessary to define the practical fields in which these components unfold. If different contexts of application would lead to different fields of competency (such as bioethics, environmental ethics or business ethics), we believe that the competency in Al ethics requires that the ethical issues related to this technology be situated in the context of rapid technological development and its impact on individuals and groups to which they belong. It is also necessary to understand how the ethical issues related to Al are part of moral dilemmas that are sometimes new iterations of moral debates and value conflicts that have a long history, but also sometimes quite new, even entirely unprecedented. It is also important to understand the ethical issues of Al in their social context (that of the conception, development and deployment of this technology), by underlining the inequalities that characterize this social context and the power dynamics that underlie it. Finally, we believe that it is essential to analyze the ethical issues of Al within the boundaries delimited by the norms, specific expectations and formal obligations that contribute to the normative framework of these technological innovations. This has led us to distinguish four fields of the competency in $\mathrm{Al}$ ethics related to A- the technical aspects of Al, B- the moral dilemmas associated with $\mathrm{Al}$, $C$ - the socio-technical context of Al and D- the normative frameworks complementary to ethics in the regulation of Al. 


\section{Technical aspects of AIS}

The first field of competency in Al ethics is related to the technical aspects of AIS. More specifically, a fundamental requirement for developing the competency in Al ethics involves having a minimal understanding of the technical processes of AIS. The rapid pace of technological development and the equally rapid evolution of the uses of technological innovations demand that the competent person in Al ethics constantly updates her knowledge of the latest technological devices, with a view to anticipating their applications and their potential effects. Moreover, the competent person must avoid basing her appreciation of these issues on a poor understanding of the technical processes or on extrapolations out of step with the current technological development, which could lead her to deal primarily with very hypothetical ethical issues. We believe that such approaches are more of a distraction, leading one away from the actual problems raised by the technological devices that currently exist (or that can be anticipated given recent developments). While there certainly is a foresight element to such an assessment of the ethical issues related to the technical aspects of AIS, we believe that an appropriate knowledge of these technical aspects prevents ethical debates from being grounded on purely speculative questions. On the other hand, this first field of competency in Al ethics also implies that the competent person in Al ethics must be able to evaluate the complexity of the relationship between human beings and technical objects. Echoing work in the philosophy of technology (Winner, 1980; Verbeek, 2005), it is essential to approach technology by questioning the idea that it is neutral, since it is only a set of tools at the disposal of human beings who can use them as they wish. The relationship that human beings have with technical objects influences their conception of the world, this relationship to technical objects being even a fundamental component of what being human is. It is therefore necessary to understand the ethical issues of $\mathrm{Al}$ in this broader framework, the competent person being able to assess the complexity of these relationships, particularly with regard to the values that are conveyed by AIS.

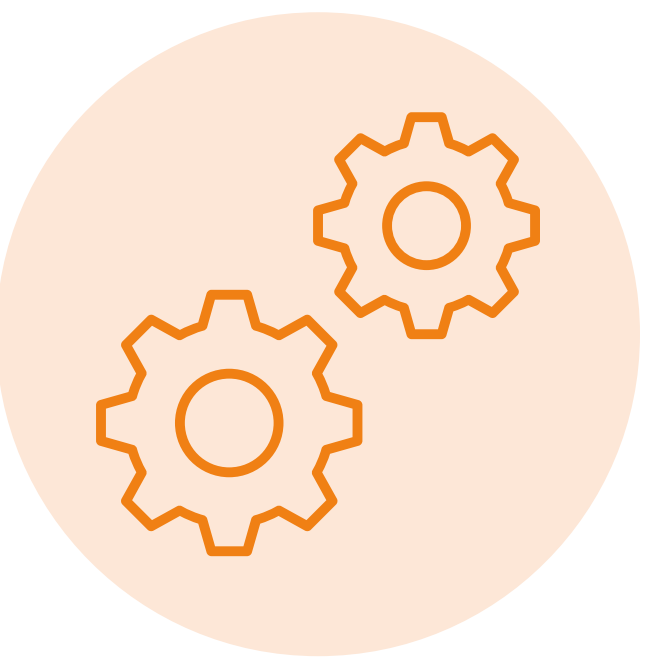




\section{Moral dilemmas related to AIS}

The second field of competency in Al ethics concerns the moral dilemmas raised by AIS. These moral dilemmas are part of conflicts of values and norms that go beyond the specific context of Al development and are rooted in a long history. The main theories in moral philosophy and the principles they propose seek to offer solutions to these dilemmas. The tensions between autonomy, wellbeing (especially in the form of beneficence and non-maleficence), privacy, security, confidentiality, consent, transparency, fairness (to name only these most classic examples) are not specific to the development of AIS, and possible resolutions of these tensions have been proposed long before the development of Al. The competent person in Al ethics will however be able to grasp how Al-related technological innovations embody these tensions and constitute a new locus for the expression of these conflicts. To do so, she must be able to understand the main theoretical approaches in moral philosophy, the tensions between them as well as their limits, and the particularities of the issues at stake in $\mathrm{Al}$ ethics, which may require the reconceptualization of certain principles derived from classical ethical frameworks (van den Hoven, 2010). Moreover, the competent person in Al ethics will also be able to appreciate the specific characteristics of ethical situations involving AIS, or even their novelty, by developing her ability to grasp the epistemological, normative and overarching issues linked to the problems related to AIS (Mittelstadt et al., 2016). In doing so, she will also be able to assess the novel value and normative conflicts that are implied by AIS, particularly with respect to explicability and traceability.

\section{The socio-technical context of AIS}

The third field of competency in Al ethics is related to the socio-technical context of AIS. Properly evaluating the ethical issues of AIS within the socioeconomic context in which they are embedded, particularly with respect to issues related to diversity, inclusion, and equality, is crucial to fully grasp the scope of these issues. Because AIS are likely, as numerous studies have shown (Noble, 2018; Eubanks, 2019), to exacerbate and automate already existing discrimination, exclusion, and inequalities toward certain groups, the competent person in $\mathrm{Al}$ ethics must be able to mobilize the conceptual and analytical resources necessary to incorporate the social aspects of ethical issues into her thinking and action. In doing so, she must also understand the ethical issues at stake in the power relations that are central to the design, development and deployment of AIS, in addition to situating them in relation to the political dynamics of which they are part. Similarly, the competent person in Al ethics must be able to identify the specific ethical issues related to AIS and their environmental impact (Crawford, 2021).
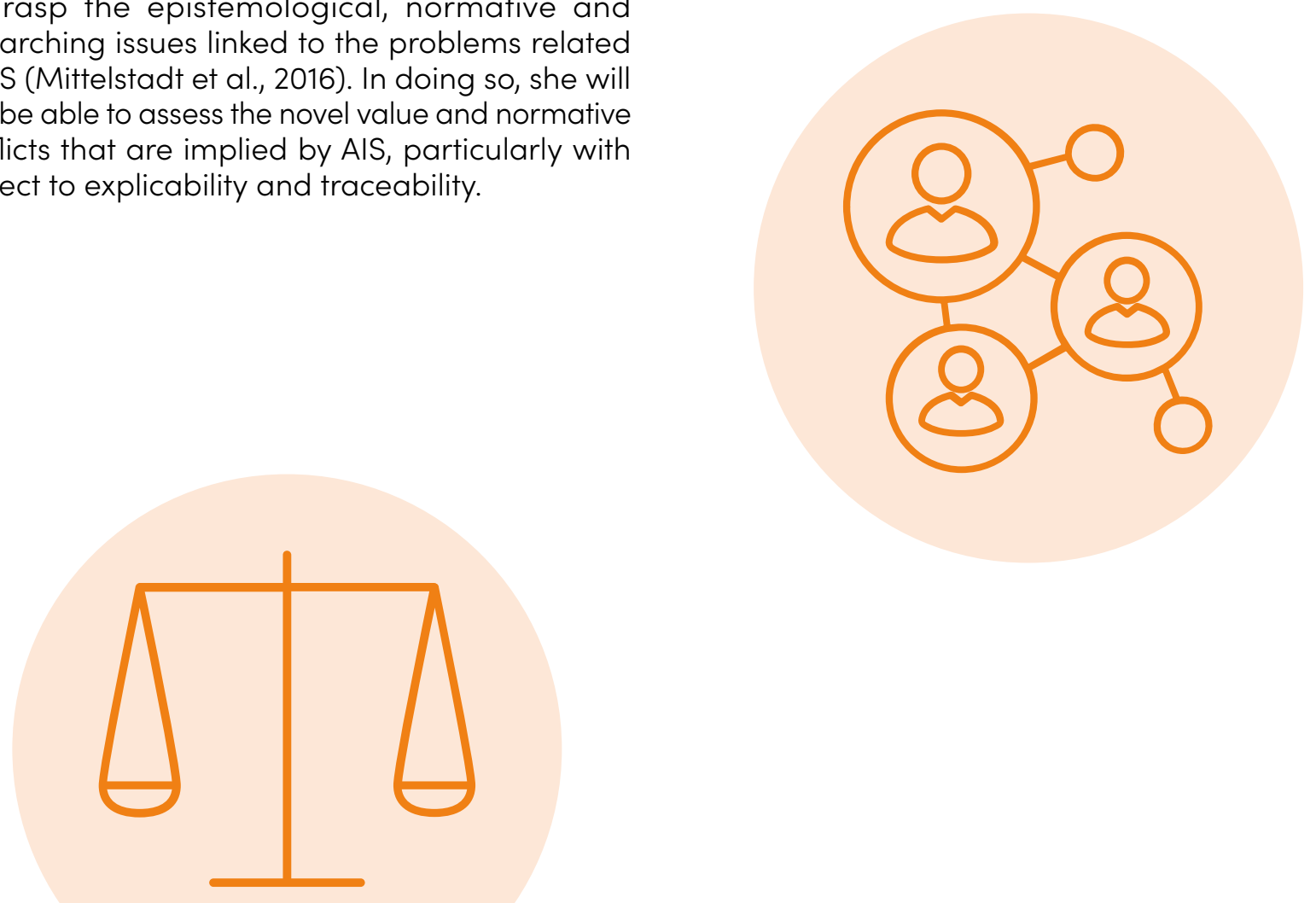


\section{Complementary normative frameworks}

The fourth field of competency in Al ethics concerns the normative frameworks complementary to ethics in the regulation of Al. It is necessary to understand the requirements for $\mathrm{Al}$ ethics within the framework of state and international law, especially with regard to privacy and personal data protection. The competent person in Al ethics should also be aware of and able to compare the main normative frameworks provided by charters and declarations in Al ethics that have been issued in academia, through international organizations and by major industry players. It is also important to be able to identify the obligations prescribed by codes of ethics and other relevant professional normative frameworks.
While we identify four different fields of competency in Al ethics and specific expectations related to each field that are then translated into the elements of competency that students must acquire, this does not imply that these fields of competency operate (or even can be analyzed) independently of one another. On the contrary, the competent person in Al ethics must be able to mobilize the appropriate resources, while interacting with others, resources possibly related to the four fields of competency in Al ethics (according to the three components described above), in order to discern, analyze, understand, and seek adequate solutions to the problems generated by a specific ethical situation involving AIS. Therefore, the intersection of the three components of the ethical competency and the four fields of competency in Al ethics has allowed us to identify 12 dimensions of competency that should contribute to structuring a satisfactory training in $\mathrm{Al}$ ethics. For each field of competency in Al ethics, we have also identified elements of competency that define more precisely the skills that students must acquire through an adequate training in Al ethics.

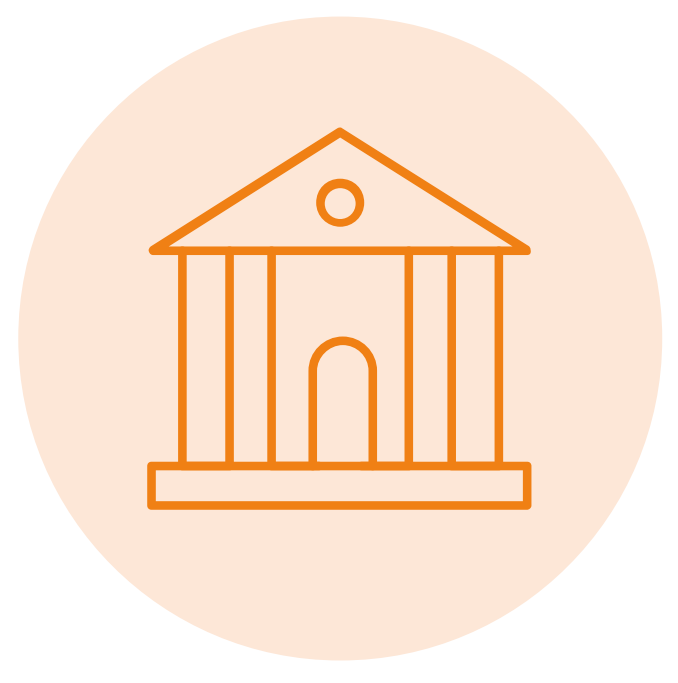


Overview of the competency framework

Competency Components

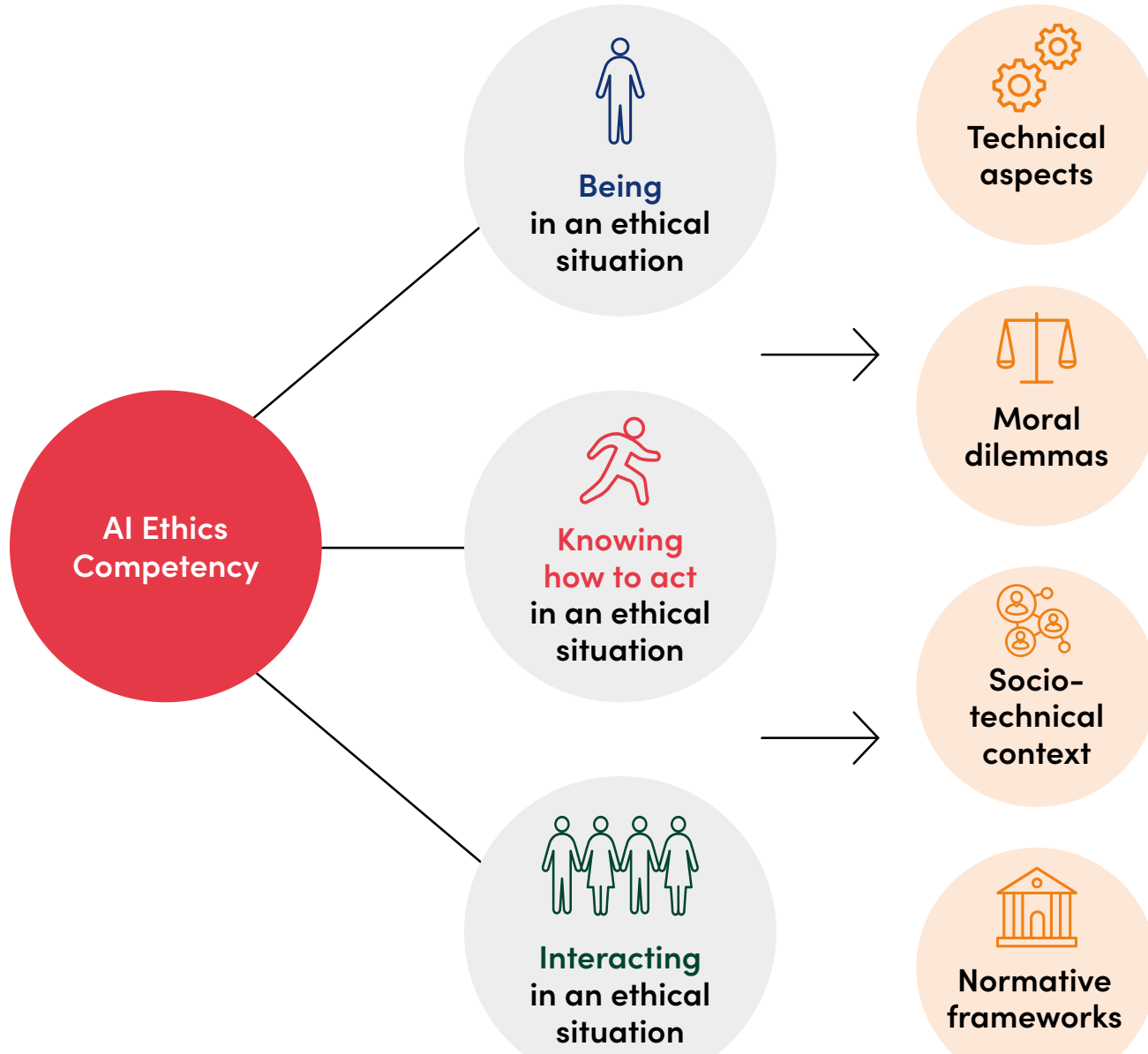

Fields

Elements

Technical

aspects

Moral

dilemmas

frameworks 


\section{Al Ethics \\ Competency Statement}

To be competent in Al ethics is to be able to act in ethical situations involving Al systems, and to do so autonomously and responsibly through the voluntary mobilization of appropriate internal and external resources.

\section{The 3 components}

\section{of ethical competence}

1. Being in an ethical situation

Ethical sensitivity

2. Knowing how to act in an ethical situation Reflective skills Dialogical skills Being in an ethical situation

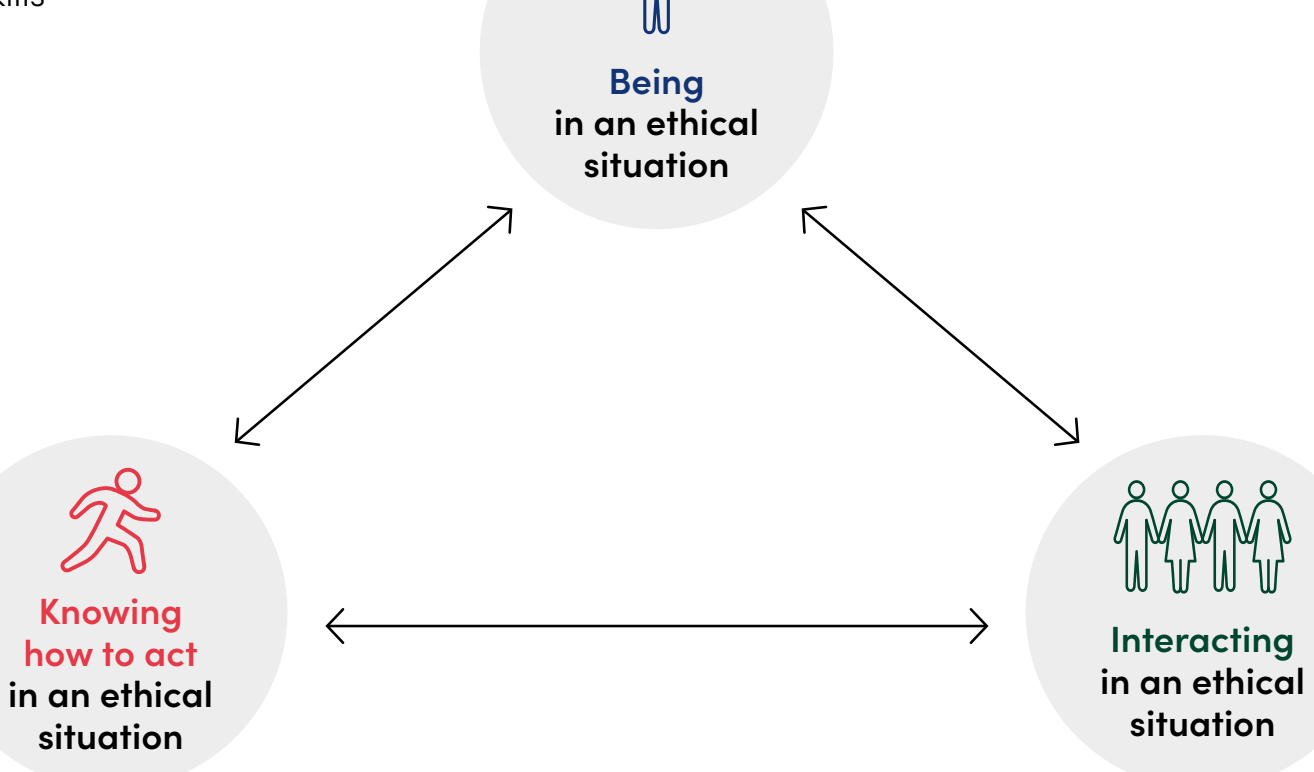


The 3 components of the Al

\section{ethics competency}

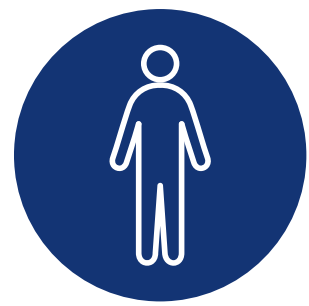

1. Being in an ethical situation

Recognize and appreciate the ethical dimension of situations involving AIS in different areas of our daily activities.

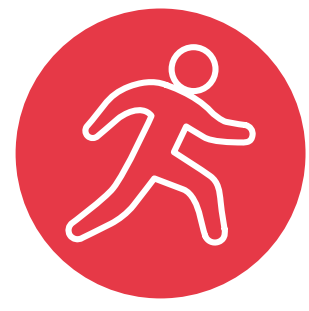

2. Knowing how to act in an ethical situation

Problematize the ethical dimension of issues related to AIS and deal with these issues autonomously in order to act in an ethical situation.

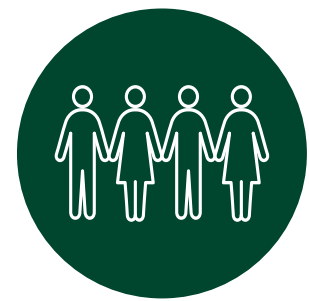

3. Interacting in an ethical situation

State one's personal position on ethical issues related to to AIS, evaluate the relevance of this position in relation to other possible positions, and deliberate in order to coordinate joint actions with others in an ethical situation.

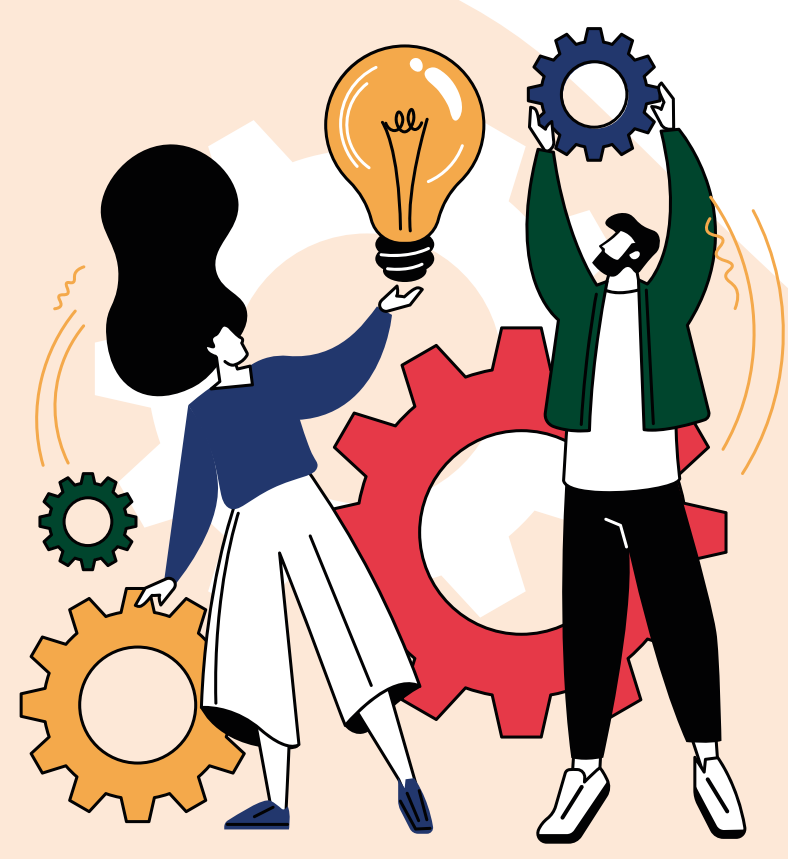


The $\mathbf{4}$ fields of competency in Al ethics

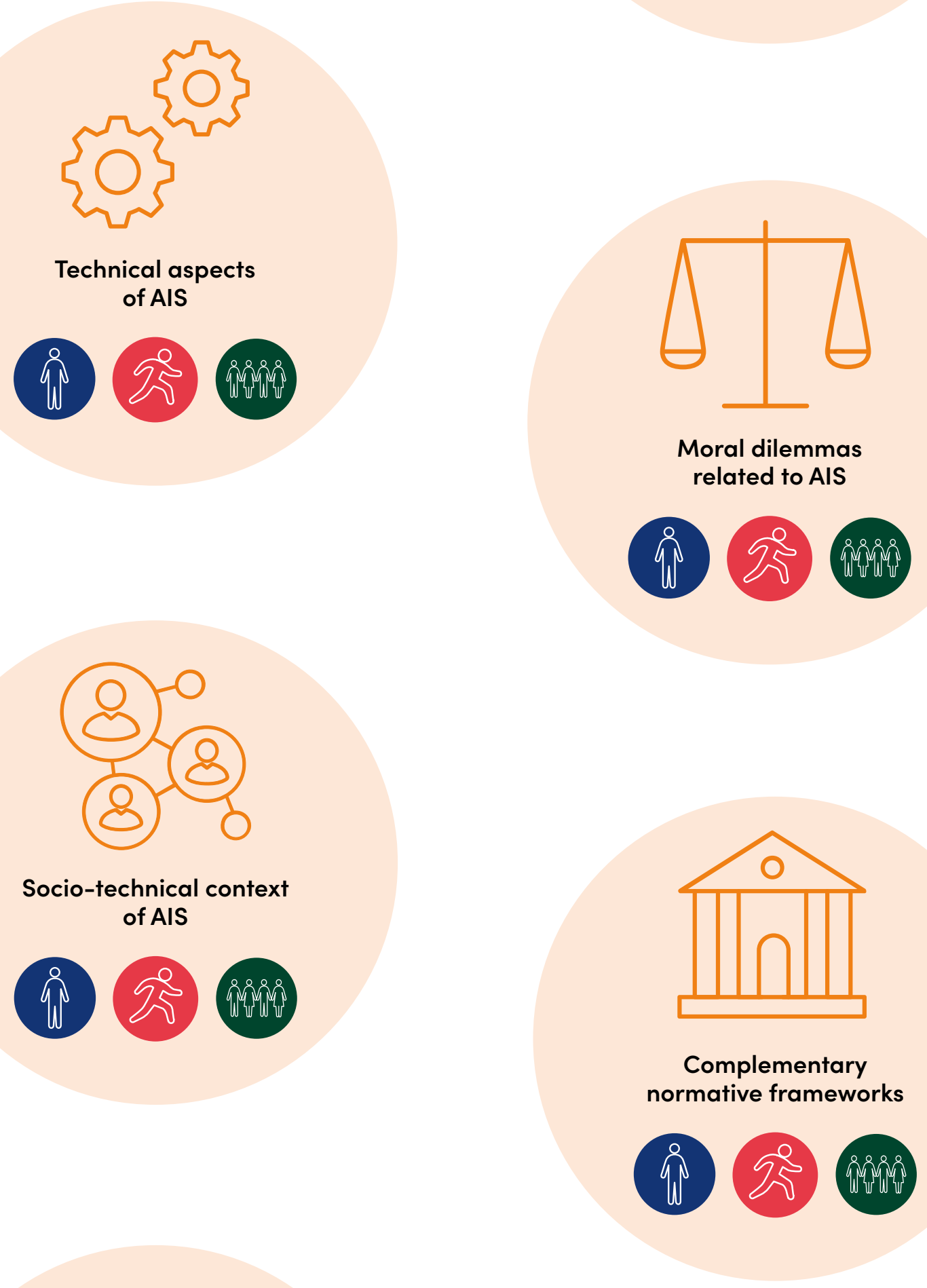




\section{A Field of competency: \\ technical aspects of AIS}

\section{DIMENSIONS OF COMPETENCY}

\section{Dimension 1A}

Identify situations in which the technical operation of AIS raises specific ethical issues, given the place of these systems in our daily lives.

\section{Dimension 2A}

Mobilize the knowledge related to the technical functioning of AIS which is necessary to address specific issues, in order to perform a reflective and critical assessment of these systems.

\section{Dimension 3A}

Present one's own understanding of the technical characteristics of AIS and their place in our daily lives, appreciate those of other stakeholders, and deliberate with a view to finding, in context, possible solutions to the specific issues identified.

\section{ELEMENTS OF COMPETENCY}

- Outline the key characteristics of AIS technical processes.

- Analyze the characteristics of AIS technical processes according to different conceptions of the interplay between human beings and technology.

For example, in this field, the competent person in Al ethics could be called upon to deploy these three dimensions of competency in dealing with the technical aspects of a particular ethical situation related to an AIS, such as that arising from the role of the YouTube algorithm in polarizing discourses, disseminating disinformation and displaying hateful or violent content'.

${ }_{1}^{1}$ Mozilla Foundation. (2021). YouTube regrets. A crowdsourced investigation into YouTube's recommendation algorithm. https://assets.mofoprod.net/network/documents/Mozilla_YouTube_Regrets_Report.pdf 


\section{Field of competency: \\ moral dilemmas related to AIS}

\section{DIMENSIONS OF COMPETENCY}

\section{Dimension 1B}

Detect moral dilemmas that arise from a situation and analyze the problems related to the use of AIS in the context of moral pluralism.

\section{Dimension 2B}

Problematize the specific moral dilemmas associated with the use of AIS by mobilizing conceptual resources and theoretical frameworks in moral philosophy in order to rationally address these issues.

\section{Dimension 3B}

Evaluate the relevance of one's personal stance on moral dilemmas related to the use of AIS by comparing it to those of other stakeholders in order to deliberate on the actions required to develop, in context, possible solutions to the specific issues identified.

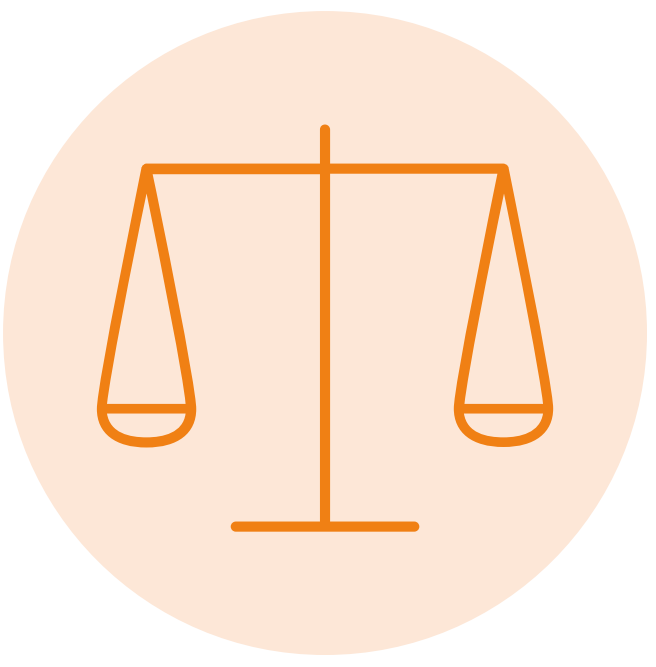

\section{ELEMENTS OF COMPETENCY}

- Identify the principles and values in conflict in particular moral dilemmas related to AIS.

- Compare different theoretical frameworks in moral philosophy that allow the conceptualization of specific moral dilemmas related to AIS.

- Assess epistemic, normative, and overarching issues related to AIS.

For example, within this field, the competent person in Al ethics could be called upon to deploy these three dimensions of competency in addressing moral dilemmas related to a particular ethical situation involving an AIS, such as that arising from the use of mobile contact tracking and COVID-19 exposure notification apps, such as COVID-Alert, particularly with respect to the tension between privacy, consent, and safety ${ }^{2}$.

\footnotetext{
${ }^{2}$ Commission de l'éthique en science et en technologie. (2020). Les enjeux éthiques de l'utilisation d'une application mobile de traçage de contacts dans le cadre de la pandémie de COVID-19 au Québec. https://www.ethique.gouv.qc.ca/media/cikcgq3i/cest-app-tracage-2020.pdf
} 


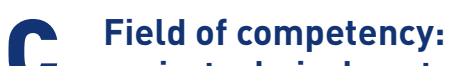 .}

\section{DIMENSIONS OF COMPETENCY}

Dimension 1C

Identify specific issues related to the socio-technical context in which AIS are designed, deployed and used.

\section{Dimension 2C}

Analyze the specific problems associated with the sociotechnical systems to which AIS belong and assess the political, social, economic, cultural, and environmental issues associated with these problems.

\section{Dimension 3C}

Discuss different perspectives on the specific issues related to the socio-technical systems to which AIS belong and anticipate the societal impacts of different possible actions in context.

\section{ELEMENTS OF COMPETENCY}

- Situate the ethical issues of AIS within the socioeconomic context in which they operate, including issues related to diversity, inclusion and equality.

- Assess the ethical issues of AIS within the political dynamics in which they are embedded.

- Identify the specific ethical issues of AIS related to their environmental impact.

For example, in this field, the competent person in Al ethics could be called upon to deploy these three dimensions of competency in addressing issues arising from the socio-technical context of a particular ethical situation related to an AIS, such as that arising from the use of Al for predictive policing, including the potentially discriminatory effects of such practices ${ }^{3}$.

${ }^{3}$ Sankin, A. et al. (2021). Crime prediction software to be free of biases: New data shows it perpetuated them. Gizmodo. https://gizmodo.com/crime-prediction-software-promised-to-be-free-of-biases-1848138977 


\section{Dield of competency: complementary normative frameworks}

\section{DIMENSIONS OF COMPETENCY}

\section{Dimension 1D}

Identify the relevant provisions of the various normative frameworks that contribute to the guidance of conduct related to the design, deployment and use of AIS.

\section{Dimension 2D}

Mobilize the various normative frameworks that apply to the specific problems associated with AIS, assess their relevance, and identify the tensions that arise from their interaction.

\section{Dimension 3D}

Outline the prioritization of norms that informs one's personal position on the specific issues associated with AIS, evaluate the prioritization that informs the position of other stakeholders in the discussion, and deliberate to find, in context, possible solutions to the particular ethical issues identified.

\section{ELEMENTS OF COMPETENCY}

- Situate the ethical issues of AIS within the framework of state and international law.

- Compare normative frameworks from Al ethics charters and declarations.

- Identify the obligations prescribed by professional codes of ethics and other relevant deontological frameworks.

For example, in this field, the competent person in Al ethics might be required to deploy these three dimensions of the competency in the mobilization and assessment of different normative frameworks applicable to a particular ethical situation related to an AIS, such as The Montreal Declaration for a Responsible Development of Artificial Intelligence ${ }^{4}$, the Private Sector Privacy Act ${ }^{5}$, or the European Union's Artificial Intelligence Act ${ }^{6}$.

\footnotetext{
${ }^{4}$ Université de Montréal. (2017). Montreal Declaration for a Responsible Development of Artificial Intelligence. https://www.montrealdeclaration-responsibleai.com

${ }^{5}$ Act Respecting the Protection of Personal Information in the Private Sector. RLRQ c P-39.

${ }^{6}$ Proposal for a Regulation of the European Parliament and of the Council Laying Down Harmonized Rules on Artificial Intelligence and Amending Certain Union Legislative Acts. (2021).

https://eur-lex.europa.eu/legal-content/EN/TXT/HTML/?uri=CELEX:52021PC0206\&from=EN
} 


\section{Graphical representation of the Al}

ethics competency framework

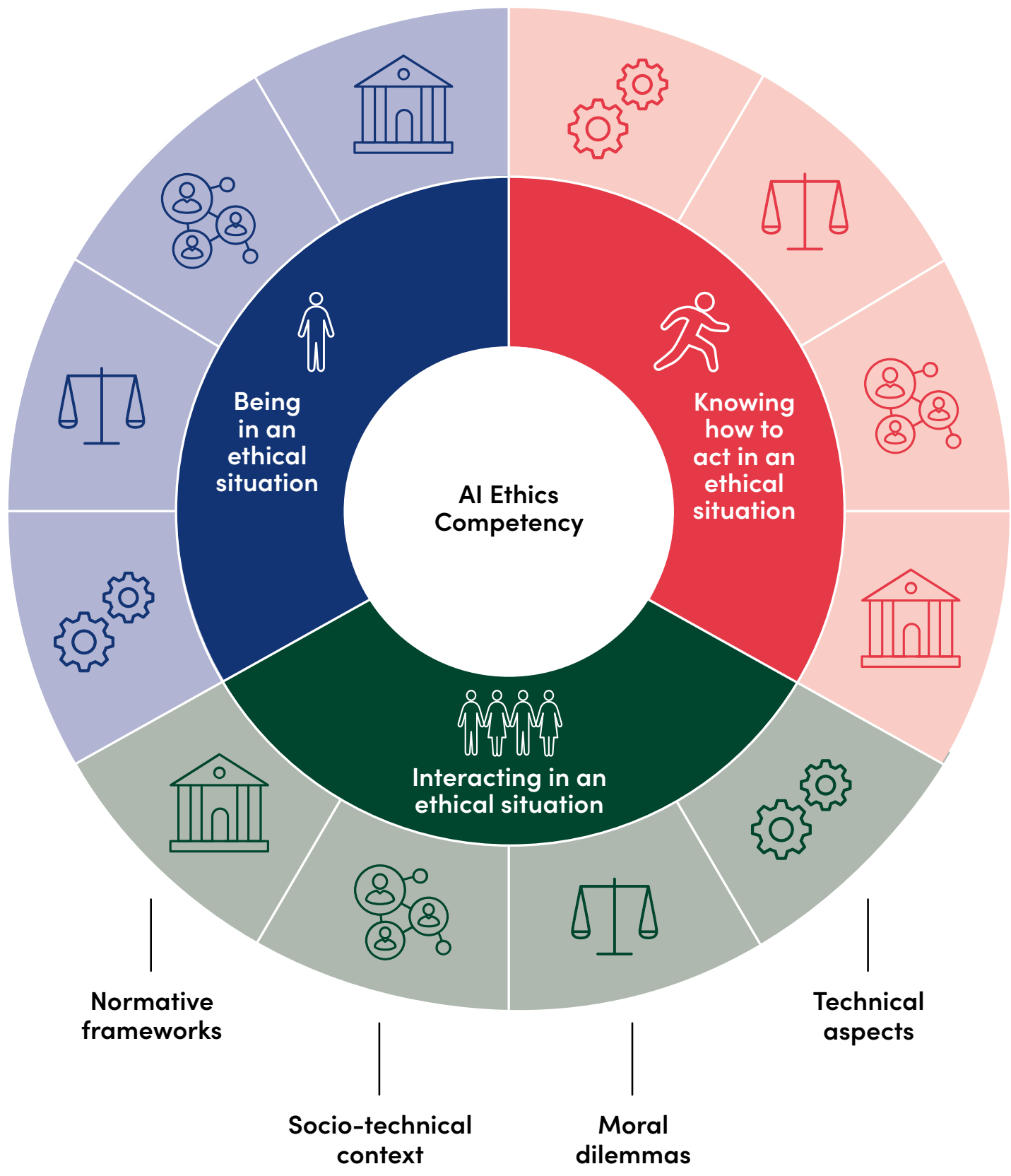




\section{Selective bibliography?}

Act Respecting the Protection of Personal Information in the Private Sector. RLRQ c P-39.

Aiguier, G. (2017). De la logique compétence à la capacitation: vers un apprentissage social de l'éthique. Éthique publique, 19(1). https://doi.org/10.4000/ethiquepublique.2907

Aiguier, G. et al. (2012). Du pragmatique au pragmatisme: quels enjeux pour la formation à l'éthique? Journal international de bioéthique, 23(3-4), 123. https://doi.org/10.3917/jib.233.0123

Boudreau, M.-C. et Montour, M. (2018). Le retour d'expérience comme dispositif de formation à l'éthique: Une pratique réflexive pour le déploiement de la compétence éthique des acteurs et des organisations. Spirale - Revue de recherches en éducation, 61(1), 83. https://doi.org/10.3917/spir.061.0083

Boudreau, M-C. (2019). La compétence éthique en milieu de travail: Une perspective pragmatiste pour sa conceptualisation et son opérationnalisation. Thèse de doctorat. Université de Sherbrooke.

Bouchard, N. (2007). La notion de compétence en éducation au Québec: une notion à "libérer". The Journal of Educational Thought, 41(1), 27. https://www.jstor.org/stable/23767249

Boutin, G. (2004). L'approche par compétences en éducation: un amalgame paradigmatique. Connexions, 81, 25. https://doi.org/10.3917/cnx.081.0025

Boyd, W. \& Newton, D. (2011). Times of change, times of turbulence: Seeking an ethical framework for curriculum development during critical transition in higher education. International Journal of Cyber Ethics in Education, 1(3). https://doi.org/10.4018/ijcee.2011070101

Briand-Lamarche, M. et al. (2018). Développement participatif d'un référentiel de compétences pour favoriser I'utilisation de la recherche en éducation: une analyse critique. Canadian Journal of Education / Revue canadienne de l'éducation, 41(2).

Brotcorne, P., Collin, S. et Schneider, E. (2019). Des recherches en éducation au domaine des technologies éducatives: Quelles dynamiques d'appropriation des approches critiques? Formation et profession, 27(3), 22. https://doi.org/10.18162/fp.2019.543

Bruneault, F. \& Sabourin Laflamme, A. (2021). Al ethics: how can information ethics provide a framework to avoid usual conceptual pitfalls? An overview. Al \& Society, 36, 757. https://doi.org/10.1007/s00146-020-01077-w

Burton, E. et al. (2017). Ethical Considerations in Artificial Intelligence Courses. Al Magazine, 38(2), 22. https://doi.org/10.1609/aimag.v38i2.2731

Chene, A. (2005). Les enseignants et le défi éthique du pragmatisme, dans Gohier. C et D. Jeffrey. (2005), Enseigner et former à l'éthique, PUL.

Clements, E. (2019). A conceptual framework for digital civics pedagogy informed by the philosophy of information. Journal of Documentation, 76(2), 571-585. https://doi.org/10.1108/JD-07-2019-0139

Coeckelbergh, M. (2021). Cascading morality after Dewey: A proposal for a pluralist meta-ethics with a subsidiarity hierarchy. Contemporary Pragmatism, 18(1), 18. https://doi.org/10.1163/18758185-bja10002

Commission de l'éthique en science et en technologie. (2020). Les enjeux éthiques de l'utilisation d'une application mobile de traçage de contacts dans le cadre de la pandémie de COVID-19 au Québec. https://www.ethique.gouv.qc.ca/media/cikcgq3i/cest-app-tracage-2020.pdf

Corteel, M., Kyrou, A. et Moulier-Boutang, Y. (2020). Pour une culture critique de I'IA. Multitudes, 78(1), 51. https://doi.org/10.3917/mult.078.0051

Coulet, J.-C. (2016). Les notions de compétence et de compétences clés: L'éclairage d'un modèle théorique fondé sur l'analyse de l'activité. Activités, 13(1). https://doi.org/10.4000/activites. 2745

Crawford, K. (2021). Atlas of Al. Yale University Press.

de Montgolfier, S. et Bonhoure, G. (2018). Enseignement des sciences et questionnement éthique: Urgence sociétale et opportunité pour l'enseignement. Journal international de bioéthique et d'éthique des sciences, $29(1), 11$. https://doi.org/10.3917/jibes.291.0011

Dewey, J. (2004). Reconstruction in Philosophy. Dover.

Eubanks. V. (2018). Automating Inequality. How High-Tech Tools Profile, Police and Punish the Poor. St. Martin's Press.

Fjeld, J. et al. (2020). Principled artificial intelligence: Mapping consensus in ethical and rights-based approaches to principles for Al. SSRN Electronic Journal. https://doi.org/10.2139/ssrn.3518482

\footnotetext{
${ }^{7}$ The publications listed in the selective bibliography do not reflect the extent of the literature review conducted as part of the first phase of the research project, as described in the methodology section, but are the sources that were used more directly in developing the competency framework. The list of publications consulted for the purposes of the literature review can be made available by the researchers upon request.
} 
Fiesler, C., Garrett, N. \& Beard, N. (2020). What do we teach when we teach tech ethics? A syllabi analysis. Proceedings of the 51st ACM Technical Symposium on Computer Science Education, 289. https://doi.org/10.1145/3328778.3366825

Floridi, L. \& Cowls, J. (2019). A unified framework of five principles for Al in society. Harvard Data Science Review, https://doi.org/10.1162/99608f92.8cd550d1

Furey, H. \& Martin, F. (2019). Al education matters: A modular approach to Al ethics education. Al Matters, 4(4), 13. https://doi.org/10.1145/3299758.3299764

Garrett, N., Beard, N. \& Fiesler, C. (2020). More than "If time allows": The role of ethics in Al education. Proceedings of the AAAI/ACM Conference on Al, Ethics, and Society, 272. https://doi.org/10.1145/3375627.3375868

Genard, J.-L. (2017). La "compétence éthique» au-delà de ses dimensions discursives et propositionnelles. Éthique publique, 19(1). https://doi.org/10.4000/ethiquepublique.2876

Goldsmith, J. \& Burton, E. (2017). Why teaching ethics to Al practitioners is important. Proceedings of the Thirty-First AAAl Conference on Artificial Intelligence, 31(1).

Gouvernement du Québec. Ministère de l'Éducation. (2019). Cadre de référence de la compétence numérique. http://www.education.gouv.qc.ca/fileadmin/site_web/documents/ministere/Cadre-reference-competence-num.pdf

Grosz, B. J. et al. (2019). Embedded EthiCS: Integrating ethics across CS education. Communications of the ACM, $62(8), 61$. https://doi.org/10.1145/3330794

Henderson, T. (2019). Teaching data ethics: We're going to ethics the heck out of this. Proceedings of the 3rd Conference on Computing Education Practice. https://doi.org/10.1145/3294016.3294017

Hess, J. L. \& Fore, G. (2017). A systematic literature review of US engineering ethics interventions. Science and Engineering Ethics, 24, 551. https://doi.org/10.1007/s11948-017-9910-6

Jay, É. (2017). Enquêter avec Dewey sur la notion de compétence: Et si la compétence éthique ne pouvait s'enseigner? Éthique publique, 19(1). https://doi.org/10.4000/ethiquepublique.2904

Jobin, A, et al. (2019). Artificial intelligence: The global landscape of ethics guidelines. Nature Machine Intelligence, $1,389$. https://doi.org/10.1038/s42256-019-0088-2

Kahn, S. et Rey, B. (2017). La notion de compétence: Une approche épistémologique. Éducation et francophonie, 44(2), 4. https://doi.org/10.7202/1039019ar

Kastrup, V. (2002). À propos de l'apprentissage de la compétence éthique. Intellectica, 2, 299. https://doi.org/10.3406/intel.2002.1672

Keulartz et al. (2002). Ethics in a technological culture. A proposal for a pragmatist approach. In Pragmatist Ethics for a Technological Culture. Kluwer.

Lacroix A., Marchildon, A. et Bégin, L. (2017). Former à l'éthique en organisation, Presses de l'Université du Québec. https://www.jstor.org/stable/j.ctt1mf6z8t.6

Léger, D. (2006). L'éducation à la sensibilité éthique en formation initiale à l'enseignement: une praxis éducative au sein d'un projet personnel de formation, Thèse de doctorat, Université du Québec à Rimouski.

Lind, M. (2011). A framework for addressing ethics in the digital age. Proceedings of the Information Systems Educators Conference, 28(1624).

Maclure, J. et Saint-Pierre, M.-N. (2018). Le nouvel âge de l'intelligence artificielle: une synthèse des enjeux éthiques. Les cahiers de propriété intellectuelle, 30(3), 741.

Maesschalck, M. (2008). Les enjeux politiques de l'apprentissage collectif de l'éthique. Revue d'éthique et de théologie morale, 251, 65. https://doi.org/10.3917/retm.251.0065

Marchildon, A. (2017). Le pouvoir de déployer la compétence éthique. Éthique publique, 19(1). https://doi.org/10.4000/ethiquepublique. 2920

Mell, L. (2018). À travers les hypostases du numérique dans l'enseignement supérieur: réflexion critique sur le développement de la culture et des compétences numériques. Lien social et Politiques, 81, 173. https://doi.org/10.7202/1056310ar

Mittelstadt, B. et al. (2016). The ethics of algorithms: Mapping the debate. Big Data \& Society, 3(2). https://doi.org/10.1177/2053951716679679

Monteiro, F., Leite, C. \& Rocha, C. (2019). Ethical education as a pillar of the future role of higher education: Analysing its presence in the curricula of engineering courses. Futures, 111, 168. https://doi.org/10.1016/j.futures.2018.02.004 
Moore, J. (2020). Towards a more representative politics in the ethics of computer science. Proceedings of the 2020 Conference on Fairness, Accountability, and Transparency, 414. https://doi.org/10.1145/3351095.3372854

Mozilla Foundation. (2021). YouTube regrets. A crowdsourced investigation into YouTube's recommendation algorithm. https://assets.mofoprod.net/network/documents/Mozilla_YouTube_Regrets_Report.pdf

Noble, S. U. (2018). Algorithms of Oppression. How Search Engines Reinforce Racism. NYU Press.

Pfeifer, G. \& Billiar, K. (2017). Teaching ethics in the context of engineering courses: A blended approach of theory and practice. 2017 ASEE Annual Conference \& Exposition Proceedings, 28916. https://doi.org/10.18260/1-2--28916

Plante, P. (2017). L'éthique hacker, un modèle éthique du numérique pour l'éducation? Éducation et francophonie, 45(1), 89. https://doi.org/10.7202/1040722ar

Point, C. (2018). Faire de la démocratie une éthique et une pédagogie. Éthique en éducation et en formation, $4,76$. https://doi.org/10.7202/1045190ar

Proposal for a Regulation of the European Parliament and of the Council Laying Down Harmonized Rules on Artificial Intelligence and Amending Certain Union Legislative Acts. (2021). https://eur-lex.europa.eu/legal-content/EN/TXT/HTML/?uri=CELEX:52021PC0206\&from=EN

Quiquerez, G. (2014). Sur quelles bases théoriques susciter un questionnement éthique en école d'ingénieurs? SHS Web of Conferences, 13, 05003. https://doi.org/10.1051/shsconf/20141305003

Sankin, A. et al. (2021). Crime prediction software to be free of biases: New data shows it perpetuated them. Gizmodo. https://gizmodo.com/crime-prediction-software-promised-to-be-free-of-biases-1848138977

Stahl, B. C. (2015). Teaching ethical reflexivity in information systems: How to equip students to deal with moral and ethical issues of emerging information and communication technologies. Journal of Information Systems Education, 22(3), 253.

Stoyanovich, J. \& Lewis, A. (2019). Teaching responsible data science: Charting new pedagogical territory. ArXiv:1912.10564 [Cs]. http://arxiv.org/abs/1912.10564

Tsamados, A. et al. (2021). The ethics of algorithms: Key problems and solutions. Al \& Society, https://doi.org/10.1007/s00146-021-01154-8

Ullern-Weité, I. (2007). Enseigner l'éthique comme expertise ou former les personnes au jugement éthique de l'action? Question didactique. Nouvelle revue de psychosociologie, 3(1), 149. https://doi.org/10.3917/nrp.003.0149

Université de Montréal. (2017). Montreal Declaration for a Responsible Development of Artificial Intelligence. https://www.montrealdeclaration-responsibleai.com

van den Hoven, J. (2010). The use of normative theories in computer ethics. In Floridi, L. (ed.) The Cambridge Handbook of Information and Computer Ethics, Cambridge University Press, 59. https://doi.org/10.1017/CBO9780511845239.005

Verbeek, P. P. (2005). What Things Do: Philosophical Reflections on Technology, Agency, and Design. Penn State: Penn State University Press.

Wiener, N. (1954). The Human Use of Human Beings: Cybernetics and Society. New York: Doubleday.

Winner, L. (1980). Do artefacts have politics? Daedalus. 109(1), 121.

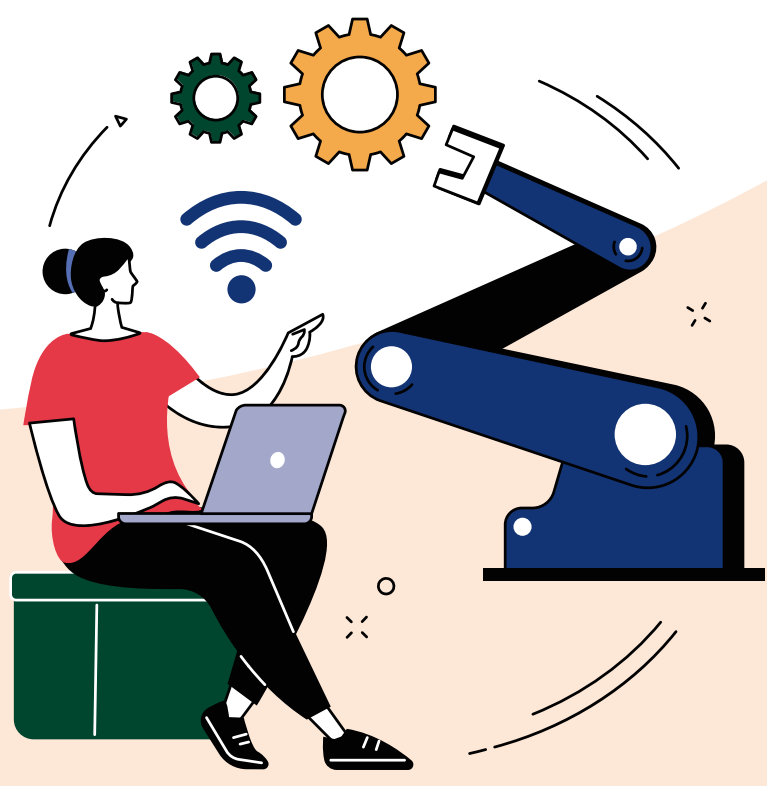


